Check for updates

Cite this: RSC Adv., 2017, 7, 35417

\title{
Alkaloids from the stems of Clausena lansium and their neuroprotective activity $\dagger$
}

\author{
Jie Liu, ${ }^{\text {ab }}$ Yi-Qian Du, ${ }^{a}$ Chuang-Jun Li, ${ }^{a}$ Li Li, ${ }^{a}$ Fang-You Chen, ${ }^{a}$ Jing-Zhi Yang, ${ }^{a}$ \\ Nai-Hong Chen (D) and Dong-Ming Zhang (D) *a
}

Eight new alkaloids, including three pairs of enantiomers (+)- $\left(2^{\prime} S, 3^{\prime} R\right)$-clauselansine $A(1 a)$ and $(-)-\left(2^{\prime} R, 3^{\prime} S\right)$ -

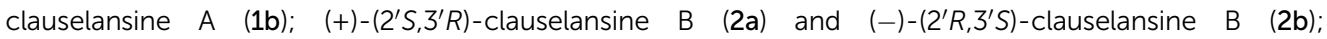
$(+)-(3 S, 4 R, 5 S, 6 S)$-clauselansine $C(3 a)$ and $(-)-(3 R, 4 S, 5 R, 6 R)$-clauselansine $C(3 \mathrm{~b}),(+)-\left(1^{\prime} R, 2^{\prime} R, 6^{\prime} R\right)$ claulansine $B(4 a)$, and $(+)-\left(1^{\prime} R, 2^{\prime} R\right)$-claulansine $D(5 a)$, together with twelve known alkaloids $(4 \mathrm{~b}, 5 \mathrm{~b}, 6 \mathrm{a}$, $6 \mathrm{~b}, 7 \mathrm{a}, 7 \mathrm{~b}$ and $8-13)$ were isolated from the stems of Clausena lansium. Their structural elucidation and stereochemistry determination were achieved by spectroscopic and chemical methods including 1D and 2D NMR experiments, especially the employment of electronic circular dichroism calculation spectra, Mosher's method, and Snatzke's method expressed by the induced circular dichroism spectrum. Compounds $1 \mathrm{~b}, 2 \mathrm{a}, 3 \mathrm{~b}, 5 \mathrm{a}$, and $5 \mathrm{~b}$ inhibited PC12 cell damage induced by Okadaic Acid, and increased cell viability from $70.5 \pm 5.4 \%$ to $83.4 \pm 4.1 \%, 91.2 \pm 10.1 \%, 83.5 \pm 7.8 \%, 89.7 \pm 4.8 \%, 83.3 \pm 5.9 \%$ at $10 \mu \mathrm{M}$, respectively.

Received 17th June 2017 Accepted 7th July 2017

DOI: 10.1039/c7ra06753d

rsc.li/rsc-advances and amide alkaloids have been isolated and identified from this plant. $^{\mathbf{1 2 - 1 4}}$ Previously, twenty new natural products including thirteen new carbazole alkaloids, ${ }^{\mathbf{1 0}, 15}$ eight alkaloid glycosides, ${ }^{\mathbf{1 6}}$ four new coumarins, ${ }^{17}$ a new amide and a new megastigmane glucoside $^{18}$ from the leaves and skeels of $C$. lansium were reported by our research group, and some of these alkaloids showed selective neuroprotective effects. In order to investigate the potential neuroprotective constituents from different parts of $C$. lansium, $n$-BuOH extract of the stems of this plant were selected for investigation. This paper reported further investigation of $n-\mathrm{BuOH}$ extract from the stems of $C$. lansium which led to the isolation and characterization of four new indole alkaloids (1a, 1b, 2a, 2b), two new amide alkaloids (3a, 3b), and two carbazole alkaloids (4a, 5a) along with twelve known compounds $(\mathbf{4 b}, \mathbf{5 b}, \mathbf{6 a}, \mathbf{6 b}, 7 \mathbf{a}, 7 \mathbf{b}, \mathbf{8 - 1 3})$ from the stems of C. lansium. The neuroprotective activities of 1-13 were also evaluated. We present herein the isolation and structural characterization of 1-13, as well as their bioactivities (Fig. 1).

\section{Results and discussion}

Compound 1 (1a/1b) was obtained as colourless oil. Its molecular formula was assigned as $\mathrm{C}_{18} \mathrm{H}_{25} \mathrm{NO}_{4}$ based on the ${ }^{13} \mathrm{C} \mathrm{NMR}$ spectroscopic data and HRESIMS $\left(\mathrm{m} / \mathrm{z} 320.1854[\mathrm{M}+\mathrm{H}]^{+}\right.$, calcd for $\mathrm{C}_{18} \mathrm{H}_{26} \mathrm{NO}_{4}, 320.1856$ ), implying seven indices of hydrogen deficiency. The IR spectrum displayed absorptions characteristic of amino $\left(3313 \mathrm{~cm}^{-1}\right)$, amide $\left(1640 \mathrm{~cm}^{-1}\right)$ and aromatic ring $\left(1671,1612\right.$, and $1439 \mathrm{~cm}^{-1}$ ) groups, and the UV spectrum showed absorptions at $\lambda_{\max } 202,223,282 \mathrm{~nm}$. The ${ }^{1} \mathrm{H}$ NMR (Table 1) spectrum showed a set of signals for 1,2,3- 
<smiles>CC(=CCc1cccc2c(C(CO)(CO)[C@](C)(O)CO)c[nH]c12)CO</smiles><smiles>CN1C(=O)[C@H](O)[C@H]2c3ccccc3[C@@H](c3ccccc3)[C@H]21</smiles>

3a 3b<smiles>COc1c2c(cc3c1[nH]c1ccccc13)[C@@H]1O[C@@H]2OC(C)(C)[C@H]1O</smiles>

$4 a$<smiles>[R]C1c2c(cc3c([nH]c4ccccc43)c2OC)[C@@H]2O[C@H]1C(C)(C)O2</smiles>

$8 \quad \mathrm{R}=\mathrm{H}$<smiles>C[C@H]1N[C@@H](C(=O)O)Cc2c1[nH]c1ccccc21</smiles>

6a $1 S, 3 S$ 6b $1 R, 3 R$<smiles></smiles><smiles>COc1c2c(cc3c1[nH]c1ccccc13)C(=O)O[C@H]2[C@H](O)C(C)(C)O</smiles>

$5 a$<smiles>O=C(/C=C/c1ccccc1)NCC(O)c1ccccc1</smiles>

12<smiles>COc1c2c(cc3c1[nH]c1ccccc13)C(=O)O[C@H]2[C@H](O)C(C)(C)O</smiles>

5b

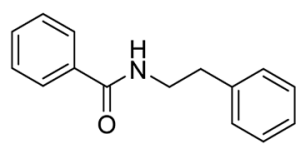

13<smiles>Cn1c2c(c(=O)c3ccccc31)C[C@@H](C(C)(C)O)O2</smiles>

$7 a \quad 2 ' R$

7 b 2 'S<smiles>Cn1c2c(c(=O)c3ccccc31)CC(O)C(C)(C)O2</smiles>

9
$11 \mathrm{R}=\mathrm{H}$

Fig. 1 Alkaloid derivatives (1-13) obtained from the stems of C. lansium.

trisubstituted benzene ring at $7.43(1 \mathrm{H}, \mathrm{d}, J=7.6 \mathrm{~Hz}, \mathrm{H}-4), 6.90$ $(1 \mathrm{H}, \mathrm{t}, J=7.4 \mathrm{~Hz}, \mathrm{H}-5), 6.85(1 \mathrm{H}, \mathrm{d}, J=6.8 \mathrm{~Hz}, \mathrm{H}-6)$, together with a doublet at $\delta_{\mathrm{H}} 7.18(1 \mathrm{H}, \mathrm{d}, J=2.4 \mathrm{~Hz}, \mathrm{H}-2)$ and a broad signal at $\delta_{\mathrm{H}} 10.80(1 \mathrm{H}, \mathrm{NH})$, which indicated a 3,7-disubstituted indole moiety. In addition, a double bond group at $\delta_{\mathrm{H}} 5.66(1 \mathrm{H}$, $\left.\mathrm{t}, J=7.3 \mathrm{~Hz}, \mathrm{H}-2^{\prime \prime}\right)$, a methylene at $3.55\left(2 \mathrm{H}, \mathrm{d}, J=7.3 \mathrm{~Hz}, \mathrm{H}-1^{\prime \prime}\right)$ and two methyls at $\delta_{\mathrm{H}} 1.70\left(3 \mathrm{H}, \mathrm{s}, \mathrm{H}-5^{\prime \prime}\right), 1.00\left(3 \mathrm{H}, \mathrm{s}, \mathrm{H}-5^{\prime}\right)$ were also exhibited in the ${ }^{1} \mathrm{H}$ NMR spectrum. The ${ }^{13} \mathrm{C}$ NMR and DEPT spectra exhibited a double bond, and four methylenes, two methines, two methyls and the remaining eight in indole moiety. The above information indicated $\mathbf{1}$ was a diprenylated indole. A comparison of the ${ }^{1} \mathrm{H}$ and ${ }^{13} \mathrm{C}$ NMR of 1 with those of hexalobines ${ }^{19}$ suggested that their structures are closely related, except for 1,3,4-trihydroxy-3-methylbut-2-yl and 4-hydroxy-3methyl-2-butenyl at C-3 and C-7 in 1. In the HMBC spectrum, the cross-peaks between $\mathrm{H}-1^{\prime} / \mathrm{C}-3\left(\delta_{\mathrm{C}} 114.2\right), \mathrm{C}-3^{\prime}\left(\delta_{\mathrm{C}} 75.0\right), \mathrm{H}-2^{\prime} /$ $\mathrm{C}-2\left(\delta_{\mathrm{C}} 123.0\right), \mathrm{C}-3 \mathrm{a}\left(\delta_{\mathrm{C}} 128.3\right), \mathrm{C}-5^{\prime}\left(\delta_{\mathrm{C}} 22.0\right), \mathrm{H}-4^{\prime} / \mathrm{C}-3^{\prime}\left(\delta_{\mathrm{C}} 75.0\right)$, C-5 ${ }^{\prime}\left(\delta_{\mathrm{C}} 22.0\right)$ demonstrated 1,3,4-trihydroxy-3-methylbut-2-yl group attached to $\mathrm{C}-3$ of the indole moiety (Fig. 2); the crosspeaks between $\mathrm{H}-1^{\prime \prime} / \mathrm{C}-6\left(\delta_{\mathrm{C}} 119.7\right)$, C-7a $\left(\delta_{\mathrm{C}} 134.4\right), \mathrm{C}-3^{\prime \prime}\left(\delta_{\mathrm{C}}\right.$ 136.3), $\mathrm{H}-2^{\prime \prime} / \mathrm{C}-7$ ( $\left.\delta_{\mathrm{C}} 123.7\right), \mathrm{C}-4^{\prime \prime}\left(\delta_{\mathrm{C}}\right.$ 66.3), $\mathrm{C}-5^{\prime \prime}\left(\delta_{\mathrm{C}} 13.7\right)$ demonstrated 4-hydroxy-3-methyl-2-butenyl group attached to C-7 of the indole moiety (Fig. 2). The NOE difference experiment displayed that a strong enhancement of $\mathrm{H}-2^{\prime \prime}$ was observed when $\mathrm{H}-4^{\prime \prime}$ was irradiated while $\mathrm{H}-2^{\prime \prime}$ was no enhanced on irradiation of $\mathrm{H}-5^{\prime \prime}$, indicating an $E$ configuration of the double bond. Thus, the structure of $\mathbf{1}$ was elucidated. The specific rotation of 1 approached zero, and no Cotton effect was found in the electronic circular dichroism (ECD) spectrum of 1, indicating a racemic mixture. Subsequent chiral resolution of 1 afforded the anticipated enantiomers $\mathbf{1 a}$ and $\mathbf{1 b}$, which showed mirror image-like ECD curves and specific rotations \{1a: $\left.[\alpha]_{\mathrm{D}}^{20}+18.7(c 0.1 \mathrm{MeOH}) ; \mathbf{1 b}:[\alpha]_{\mathrm{D}}^{20}-17.0(c 0.1 \mathrm{MeOH})\right\}$. In order to confirm the absolute configuration of the $1^{\prime}, 3^{\prime}, 4^{\prime}$-triol of $\mathbf{1 b}$, 1b was treated with 2,2-dimethoxypropane and pyridinium $p$-toluene sulfonate and converted into its acetonide 1c (Fig. 3). According to $1 \mathrm{D}$ and $2 \mathrm{D}$ NMR, 1c was determined similar to pyrido $[3,4-b]$ pyrano[3,4- $b]$ indoles. ${ }^{20}$ In order to confirm the absolute configuration of 1c, the ECD calculations were also performed for the four configurations $2^{\prime} R, 3^{\prime} S-, 2^{\prime} R, 3^{\prime} R-, 2^{\prime} S, 3^{\prime} R-$, and $2^{\prime} S, 3^{\prime} S$-1c using the time-dependent density functional theory (TDDFT) method at the $\mathrm{B}_{3} \mathrm{LYP} / 6-31 \mathrm{G}(\mathrm{d})$ level. ${ }^{21,22}$ The calculated ECD spectrum for $2^{\prime} R, 3^{\prime} S$ - and $2^{\prime} R, 3^{\prime} R$-1c enantiomer agreed with the experimental ECD data (Fig. 4 ) of 1c. Thus, the absolute configuration at $\mathrm{C}-2^{\prime}$ of $1 \mathrm{c}$ was $2^{\prime} R$. In addition, the absolute configuration of the $3^{\prime}, 4^{\prime}$-diol moiety of $1 \mathrm{c}$ was determined using induced CD spectra by Snatzke's method. ${ }^{23,24} \mathrm{~A}$ positive Cotton effect at $323 \mathrm{~nm}$ (Fig. 5) in the induced CD spectrum indicated the $3^{\prime} S$ configuration for $1 \mathrm{c}$ by means of the empirical helicity rule. According to the above information, the 
Table $1{ }^{1} \mathrm{H}$ and ${ }^{13} \mathrm{C}$ NMR spectroscopic data of compounds $1,1 \mathrm{c}$, and 2 ( $\delta$ in ppm, $\mathrm{J}$ in $\mathrm{Hz}$ )

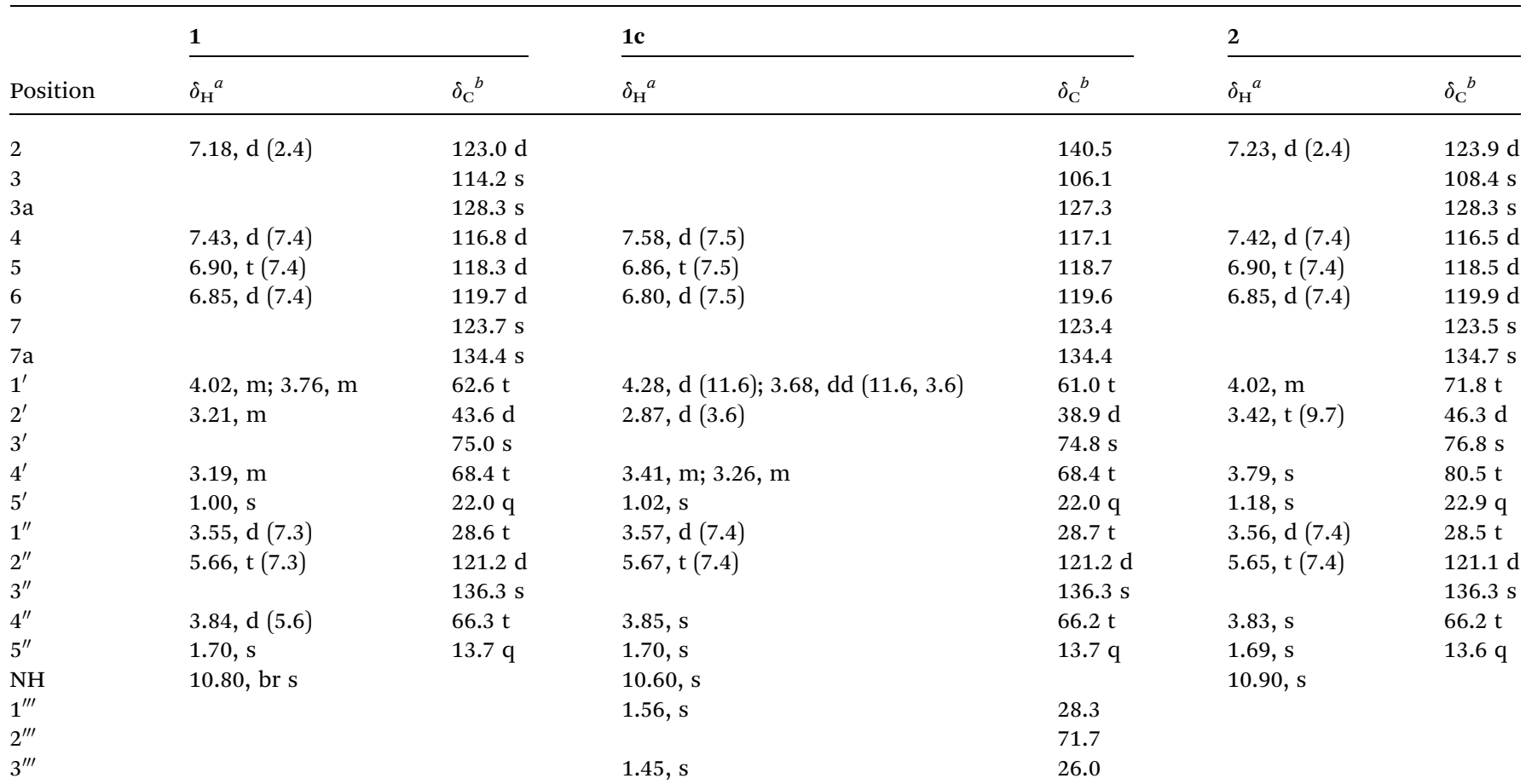

${ }^{a}$ In DMSO- $d_{6}(600 \mathrm{MHz}){ }^{b}$ In DMSO- $d_{6}(150 \mathrm{MHz})$. Coupling constants $(J)$ in Hz are given in parentheses. The assignments were based on HSQC and HMBC experiments.

absolute configuration of $\mathbf{1 b}$ was $2^{\prime} R, 3^{\prime} S$, and then the absolute configuration of 1a was $2^{\prime} S, 3^{\prime} R$. Therefore, compounds $1 \mathrm{a}$ and 1b were given the trivial names $(+)-\left(2^{\prime} S, 3^{\prime} R\right)$-clauselansine $\mathrm{A}$ and $(-)-\left(2^{\prime} R, 3^{\prime} S\right)$-clauselansine $\mathrm{A}$, respectively.

Compound $2(\mathbf{2 a} / \mathbf{2} \mathbf{b})$ was obtained as a white powder. Its molecular formula $\mathrm{C}_{18} \mathrm{H}_{23} \mathrm{NO}_{3}$ was deduced from the HRESIMS $\left(m / z 302.1758[\mathrm{M}+\mathrm{H}]^{+}\right.$, calcd for $\left.\mathrm{C}_{18} \mathrm{H}_{24} \mathrm{NO}_{3}, 302.1751\right)$ and ${ }^{13} \mathrm{C}$ NMR spectroscopic data, corresponding with eight indices of hydrogen deficiency. The ${ }^{1} \mathrm{H}$ and ${ }^{13} \mathrm{C}$ NMR of 2 displayed signals characteristic of diprenylated indole, which were similar to these reported for compound $\mathbf{1}$. The only difference between 2 and 1 was that $\mathrm{OH}-1^{\prime}$ and $\mathrm{OH}-4^{\prime}$ of 1,3,4-trihydroxy-3-methylbut2-yl group in 1 is formed five-membered oxygen ring in 2 . This was supported further by the HMBC correlations between $\mathrm{H}-1^{\prime}$ $\left(\delta_{\mathrm{H}} 4.02\right)$ and $\mathrm{C}-4^{\prime}\left(\delta_{\mathrm{C}} 80.5\right)$ and $\mathrm{H}-4^{\prime}\left(\delta_{\mathrm{H}} 3.79\right)$ and $\mathrm{C}-1^{\prime}\left(\delta_{\mathrm{C}} 71.8\right)$. The NOE difference experiment displayed that a strong enhancement of $\mathrm{H}-2^{\prime \prime}$ was observed when $\mathrm{H}-4^{\prime \prime}$ was irradiated, while $\mathrm{H}-2^{\prime \prime}$ was no enhanced on irradiation of $\mathrm{H}-5^{\prime \prime}$, indicating
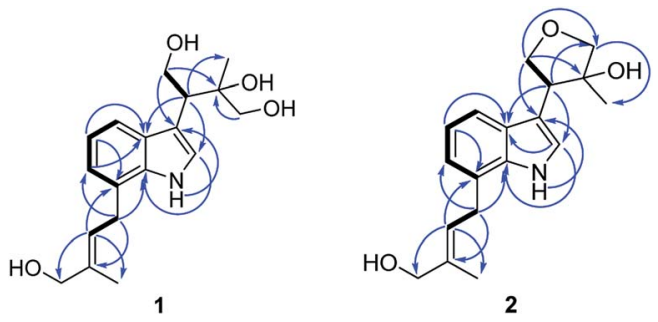

Fig. 2 Key ${ }^{1} \mathrm{H},{ }^{1} \mathrm{H}-\mathrm{COSY}$ and $\mathrm{HMBC}$ correlations of compound 1 and 2 . an $E$ configuration of the double bond. Thus, the structure of 2 was elucidated.

The specific rotation of 2 approached zero, and no Cotton effect was found in the electronic circular dichroism (ECD) spectrum of 2 , indicating a racemic mixture. Subsequent chiral resolution of $\mathbf{2}$ afforded the anticipated enantiomers $2 \mathbf{a}$ and $\mathbf{2 b}$, which showed mirror image-like ECD curves and specific rotations $\left\{2 \mathrm{a}:[\alpha]_{\mathrm{D}}^{20}+28.0(c 0.1 \mathrm{MeOH}) ; 2 \mathbf{b}:[\alpha]_{\mathrm{D}}^{20}-32.6(c 0.1 \mathrm{MeOH})\right\}$. In order to confirm the absolute configuration of the enantiomers $\mathbf{2 a}$ and $\mathbf{2 b}$, a systematic conformational analysis and optimization were performed for $\mathbf{2 a}$ and $\mathbf{2} \mathbf{b}$ using the same method applied to $\mathbf{1 a}$ and $\mathbf{1 b}$. A comparison of the theoretically

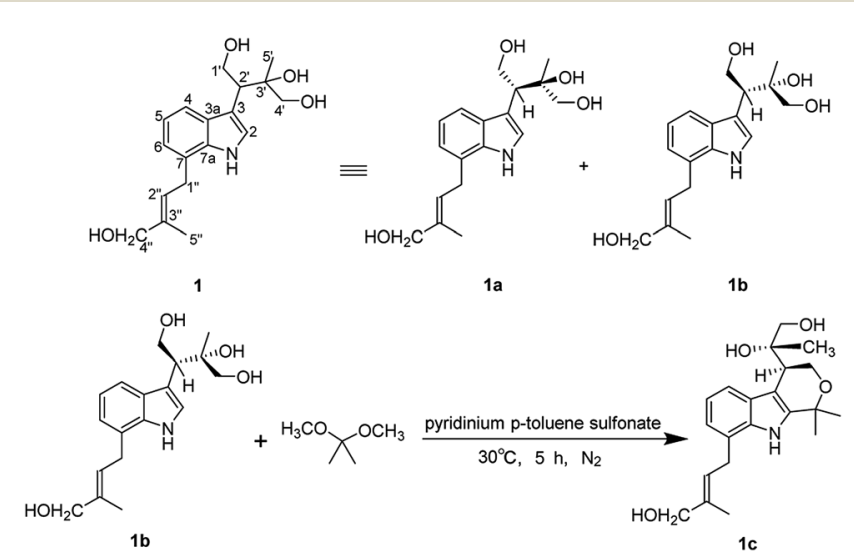

Fig. 3 The isolation of 1 to $1 \mathrm{a}$ and $1 \mathrm{~b}$ and the action of compound $1 \mathrm{~b}$ to its acetonide derivative $1 \mathrm{c}$. 


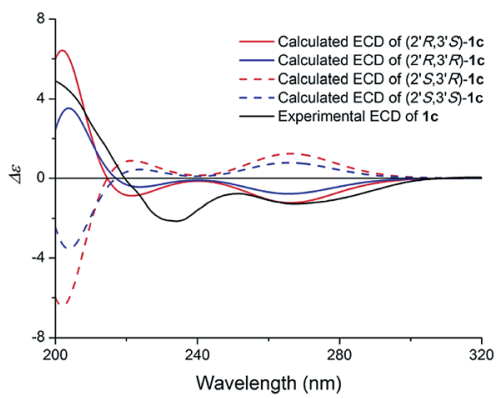

Fig. 4 Calculated ECD spectra of $\left(2^{\prime} R, 3^{\prime} S\right)-1 \mathrm{c},\left(2^{\prime} R, 3^{\prime} R\right)-1 \mathrm{c},\left(2^{\prime} S, 3^{\prime} R\right)-$ $1 c,\left(2^{\prime} S, 3^{\prime} S\right)-1 \mathrm{c}$ and the experimental ECD spectrum of (1c) in $\mathrm{MeOH}$.

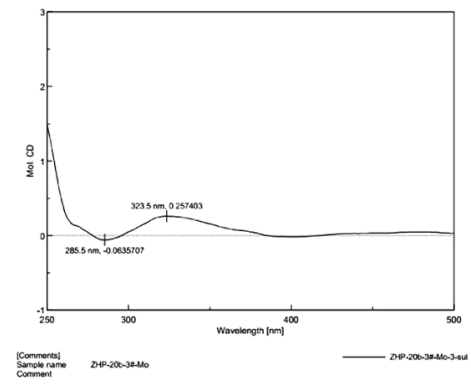

Fig. 5 CD spectrum of compound 1c in a DMSO of dimolybdenum tetraacetate (the inherent CD of the diol was subtracted).

calculated and experimental ECD curves (Fig. 6) demonstrated that the configuration of 2a was $2^{\prime} S, 3^{\prime} R$ and the configuration of 2b was $2^{\prime} R, 3^{\prime} S$. According to the structures of $\mathbf{1 a}$ and $\mathbf{2 a}$, we speculate that $2 \mathrm{a}$ was possibly generated by dehydration of $\mathbf{1 a}$, which means the configuration of $2 \mathbf{a}$ was the same as $\mathbf{1 a}$. And $\mathbf{2 b}$ was also possibly generated by dehydration of $\mathbf{1 b}$, which means the configuration of $\mathbf{2} \mathbf{b}$ was the same as $\mathbf{1} \mathbf{b}$. Thus, $\mathbf{2 a}$ has a $2^{\prime} S, 3^{\prime} R$-configuration and $2 \mathbf{b}$ has a $2^{\prime} R, 3^{\prime} S$-configuration. Therefore, compounds $\mathbf{2 a}$ and $\mathbf{2} \mathbf{b}$ were given the trivial names $(+)-\left(2^{\prime} S, 3^{\prime} R\right)$-clauselansine $\mathrm{B}$ and $(+)-\left(2^{\prime} R, 3^{\prime} S\right)$-clauselansine $\mathrm{B}$, respectively.

Compound $3(\mathbf{3 a} / \mathbf{3} \mathbf{b})$ was obtained as a white solid. Its molecular formula was assigned as $\mathrm{C}_{18} \mathrm{H}_{17} \mathrm{NO}_{2}$ based on the ${ }^{13} \mathrm{C}$ NMR spectroscopic data and HRESIMS $\left(\mathrm{m} / \mathrm{z} 280.1333[\mathrm{M}+\mathrm{Na}]^{+}\right.$, calcd for $\mathrm{C}_{18} \mathrm{H}_{17} \mathrm{NO}_{2} \mathrm{Na}$, 280.1332), implying eleven indices of hydrogen deficiency. The IR spectrum displayed absorptions
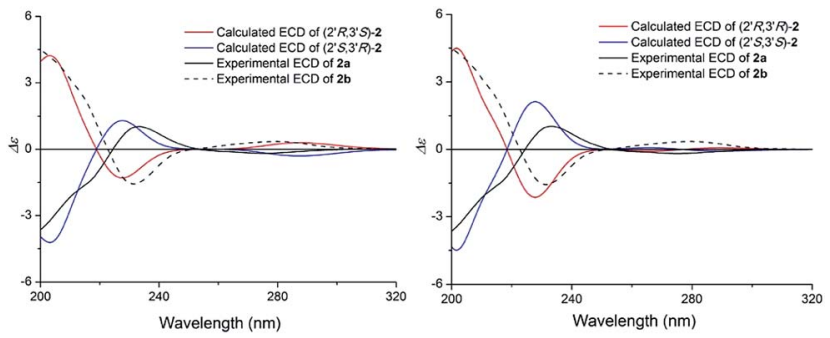

Fig. 6 Calculated ECD spectra of $\left(2^{\prime} R, 3^{\prime} S\right)-2,\left(2^{\prime} S, 3^{\prime} R\right)-2,\left(2^{\prime} R, 3^{\prime} R\right)-2$, $\left(2^{\prime} S, 3^{\prime} S\right)-2$ and the experimental ECD spectrum of (+)- and (-)-clauselansine $\mathrm{B}(2 \mathrm{a} / 2 \mathrm{~b})$ in $\mathrm{MeOH}$. characteristic of hydroxyl $\left(3320 \mathrm{~cm}^{-1}\right)$, carbonyl $\left(1678 \mathrm{~cm}^{-1}\right)$ and aromatic groups $\left(1601,1483\right.$, and $\left.1454 \mathrm{~cm}^{-1}\right)$. The ${ }^{1} \mathrm{H}$ NMR spectrum showed nine aromatic protons [ring A: $\delta_{\mathrm{H}} 6.92(1 \mathrm{H}, \mathrm{d}$, $\left.J=7.6 \mathrm{~Hz}, \mathrm{H}-3^{\prime}\right), 7.23\left(1 \mathrm{H}\right.$, overlapped, $\left.\mathrm{H}-4^{\prime}\right), 7.31\left(1 \mathrm{H}, \mathrm{m}, \mathrm{H}-5^{\prime}\right)$ and $6.23\left(1 \mathrm{H}, \mathrm{d}, J=7.6 \mathrm{~Hz}, \mathrm{H}-6^{\prime}\right)$; ring $\mathrm{B}: \delta_{\mathrm{H}} 6.98(2 \mathrm{H}, \mathrm{d}, J=$ $\left.7.1 \mathrm{~Hz}, \mathrm{H}-2^{\prime \prime}, 6^{\prime \prime}\right), 7.27\left(2 \mathrm{H}, \mathrm{m}, \mathrm{H}-3^{\prime \prime}, 5^{\prime \prime}\right), 7.23(1 \mathrm{H}$, overlapped, $\mathrm{H}-$ $\left.4^{\prime \prime}\right)$ ], together with four methine groups at $\delta_{\mathrm{H}} 4.11(1 \mathrm{H}, \mathrm{d}, J=$ $8.3 \mathrm{~Hz}, \mathrm{H}-3), 3.77(1 \mathrm{H}, \mathrm{dd}, J=8.3,5.3 \mathrm{~Hz}, \mathrm{H}-4), 4.66(1 \mathrm{H}, \mathrm{t}, J=$ $8.3 \mathrm{~Hz}, \mathrm{H}-5), 4.77(1 \mathrm{H}, \mathrm{d}, J=8.3 \mathrm{~Hz}, \mathrm{H}-6)$, and a hydroxyl group at $\delta_{\mathrm{H}} 5.97(1 \mathrm{H}, \mathrm{s})$. The ${ }^{13} \mathrm{C}$ NMR spectrum exhibited twelve aromatic carbons, one carbonyl $\delta_{\mathrm{C}} 174.1$, one oxymethine $\delta_{\mathrm{C}}$ 75.0 , three methines $\left(\delta_{\mathrm{C}} 52.3,53.3,65.2\right)$, and one methyl $\left(\delta_{\mathrm{C}}\right.$ 29.6). The ${ }^{1} \mathrm{H},{ }^{1} \mathrm{H}$-COSY correlations (Fig. 7) suggested one OCH-CH-CH-CH fragment. The ${ }^{1} \mathrm{H}$ and ${ }^{13} \mathrm{C}$ NMR data (Table 2) also indicated 1,2-disubstituted and monosubstituted aromatic units (ring A and B) and one methyl group. The HMBC correlations (Fig. 6) of $\mathrm{H}-4$ with C-2 ${ }^{\prime}\left(\delta_{\mathrm{C}} 144.7\right)$ and C-6 ${ }^{\prime}\left(\delta_{\mathrm{C}} 124.3\right) ; \mathrm{H}-5$ with C-2 $2^{\prime}\left(\delta_{\mathrm{C}} 144.7\right)$ and $\mathrm{C}-1^{\prime \prime}\left(\delta_{\mathrm{C}} 140.7\right) ; \mathrm{H}-6$ with $\mathrm{C}-3^{\prime}\left(\delta_{\mathrm{C}} 125.8\right)$ and $\mathrm{C}-2^{\prime \prime} / \mathrm{C}-6^{\prime \prime}\left(\delta_{\mathrm{C}} 129.6\right)$ showed that ring A was connected at C4 and $\mathrm{C}-6$, and ring $\mathrm{B}$ was connected at C- 6 . The above information coupled with biogenetic considerations and literature references indicated 3 was similar to the dehydro-derivative of neoclausenamide. ${ }^{25,26}$ Its relative configuration was established on the basis of NOESY correlations (Fig. 7). The NOESY correlations of $\mathrm{H}-4$ with $\mathrm{H}-5, \mathrm{H}-5$ with $\mathrm{H}-4, \mathrm{H}-6, \mathrm{~N}-\mathrm{CH}_{3}$ and $\mathrm{H}-6$ with $\mathrm{H}-5, \mathrm{H}-6^{\prime \prime}, \mathrm{H}-3$ with $\mathrm{H}-2^{\prime \prime}$ showed that $\mathrm{H}-4, \mathrm{H}-5$ and $\mathrm{H}-6$ were $\beta$ orientation, while $\mathrm{H}-3$ was $\alpha$ orientation. Thus, compound 3 (clauselansine C) was fully identified.

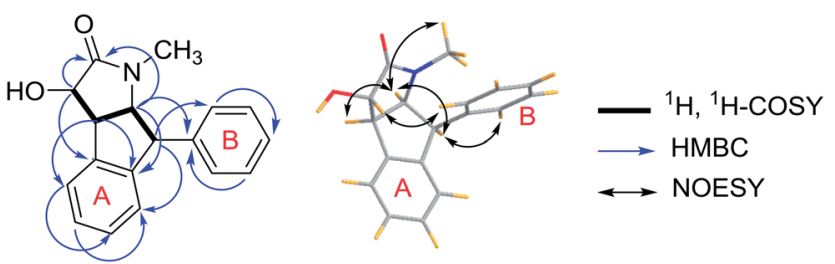

Fig. 7 Key ${ }^{1} \mathrm{H},{ }^{1} \mathrm{H}$-COSY, HMBC and NOESY correlations of compound 3.

Table $2{ }^{1} \mathrm{H}$ and ${ }^{13} \mathrm{C}$ NMR spectroscopic data of compounds 3 ( $\delta$ in ppm, $\mathrm{J}$ in $\mathrm{Hz}$ )

\begin{tabular}{|c|c|c|c|c|c|}
\hline \multirow[b]{2}{*}{ Position } & \multicolumn{2}{|l|}{3} & \multirow[b]{2}{*}{ Position } & \multicolumn{2}{|l|}{3} \\
\hline & $\delta_{\mathrm{H}}{ }^{a}$ & $\delta_{\mathrm{C}}^{b}$ & & $\delta_{\mathrm{H}}{ }^{a}$ & $\delta_{\mathrm{C}}^{b}$ \\
\hline 2 & & $174.1 \mathrm{~s}$ & $5^{\prime}$ & $7.31, \mathrm{~m}$ & 127.7 \\
\hline 3 & $4.11, \mathrm{~d}(8.3)$ & $75.0 \mathrm{~d}$ & $6^{\prime}$ & $7.45, \mathrm{~d}(7.6)$ & 124.3 \\
\hline 4 & 3.77 , dd $(8.3,5.3)$ & $52.3 \mathrm{~d}$ & $1^{\prime \prime}$ & & 140.7 \\
\hline 5 & $4.66, \mathrm{t}(8.3)$ & $65.2 \mathrm{~d}$ & $2^{\prime \prime}, 6^{\prime \prime}$ & $6.98, \mathrm{~d}(7.1)$ & 129.6 \\
\hline 6 & $4.77, \mathrm{~d}(8.3)$ & $53.3 \mathrm{~d}$ & $3^{\prime \prime}, 5^{\prime \prime}$ & $7.27, \mathrm{~m}$ & 128.2 \\
\hline $1^{\prime}$ & & $142.8 \mathrm{~s}$ & $4^{\prime \prime}$ & $7.23^{c}$ & 126.9 \\
\hline $2^{\prime}$ & & $144.7 \mathrm{~s}$ & $\mathrm{~N}-\mathrm{CH}_{3}$ & $2.10, \mathrm{~s}$ & 29.6 \\
\hline $3^{\prime}$ & $6.92, \mathrm{~d}(7.6)$ & $125.8 \mathrm{~d}$ & $\mathrm{OH}$ & $5.97, \mathrm{~s}$ & \\
\hline $4^{\prime}$ & $7.23^{c}$ & $128.0 \mathrm{~d}$ & & & \\
\hline
\end{tabular}

${ }^{a}$ In DMSO- $d_{6}(600 \mathrm{MHz}) .{ }^{b}$ In DMSO- $d_{6}(150 \mathrm{MHz}) .{ }^{c}$ Signal overlapped. Coupling constants $(J)$ in $\mathrm{Hz}$ are given in parentheses. The assignments were based on HSQC and HMBC experiments. 
The specific rotation of 3 approached zero, and no Cotton effect was found in the electronic circular dichroism (ECD) spectrum of 3, indicating a racemic mixture. Subsequent chiral resolution of $\mathbf{3}$ afforded the anticipated enantiomers $\mathbf{3 a}$ and $\mathbf{3 b}$, which showed mirror image-like ECD curves and specific rotations $\left\{3 \mathbf{a}:[\alpha]_{\mathrm{D}}^{20}+17.9(c 0.1 \mathrm{MeOH}) ; 3 \mathbf{b}:[\alpha]_{\mathrm{D}}^{20}-22.0(c 0.1 \mathrm{MeOH})\right\}$. Compound 3a was treated with $(R)$ - and $(S)-\boldsymbol{\alpha}$-methoxy- $\boldsymbol{\alpha}$-(trifluoromethyl)phenylacetyl chloride (MTPA-Cl) in anhydrous $\mathrm{CH}_{2} \mathrm{Cl}_{2}$ to afforded the 3a- $(S)$-MTPA ester (3aa) and 3a-( $(R)$-MTPA ester (3ab), respectively. The $\Delta \delta_{\mathrm{H}}^{\mathrm{SR}}$ values were calculated as shown in Fig. 8. Application of Mosher's rule ${ }^{27}$ revealed that 3a had the $3 S, 4 R, 5 S, 6 S$ configuration. Meanwhile, the absolute configuration of $\mathbf{3} \mathbf{b}$ was assigned with the $3 R, 4 S, 5 R, 6 R$-configuration. In order to confirm the absolute configuration of the enantiomers $3 \mathbf{a}$ and $\mathbf{3 b}$, the ECD calculations were also performed for the two configurations $3 S, 4 R, 5 S, 6 S$ - and $3 R, 4 S, 5 R, 6 R$ 3 using the time-dependent density functional theory (TDDFT) method at the $\mathrm{B}_{3} \mathrm{LYP} / 6-31 \mathrm{G}$ (d) level. ${ }^{21,22}$ The calculated ECD spectrum for $3 S, 4 R, 5 S, 6 S-3$ agreed with the experimental ECD data (Fig. 9) of 3a. The calculated ECD spectrum for $3 R, 4 S, 5 R, 6 R-3$ was in good accordance with the experimental spectrum of $\mathbf{3 b}$ (Fig. 9). Thus, $3 \mathbf{a}$ has a $3 S, 4 R, 5 S, 6 S$ configuration and $3 \mathbf{b}$ has a $3 R, 4 S, 5 R, 6 R$ configuration. Therefore, compounds $3 \mathbf{a}$ and $\mathbf{3 b}$ were given the trivial names $(+)-(3 S, 4 R, 5 S, 6 S)$-clauselansine $\mathrm{C}$ and $(-)-(3 R, 4 S, 5 R, 6 R)$-clauselansine $\mathrm{C}$, respectively.

Compound $4(\mathbf{4 a} / \mathbf{4} \mathbf{b})$ was obtained as a white powder. Its molecular formula was determined as $\mathrm{C}_{19} \mathrm{H}_{19} \mathrm{NO}_{4}$ on the basis of its ${ }^{13} \mathrm{C}$ NMR and HRESIMS $\left(\mathrm{m} / z 326.1398[\mathrm{M}+\mathrm{H}]^{+}\right.$, calcd for $\mathrm{C}_{19} \mathrm{H}_{20} \mathrm{NO}_{4}$ 326.1387), corresponding with eleven indices of hydrogen deficiency. Its NMR data (Table 3) was almost identical to those of claulansine B. ${ }^{10}$ Chiral separation of $\mathbf{4}$ afforded a pair of enantiomer $4 \mathbf{a}\left\{[\alpha]_{\mathrm{D}}^{20}+142.7(c 0.1 \mathrm{MeOH})\right\}$ and $\mathbf{4 b}$

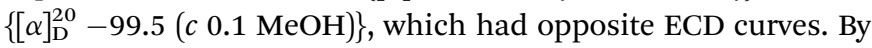

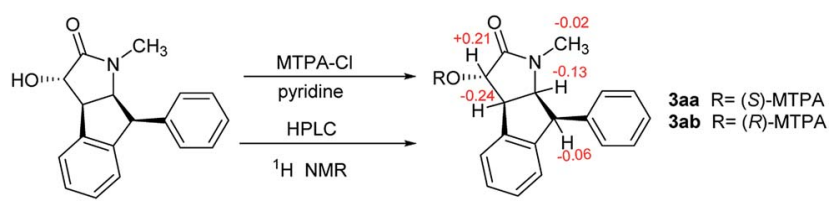

Fig. 8 The Mosher's method of 3a.

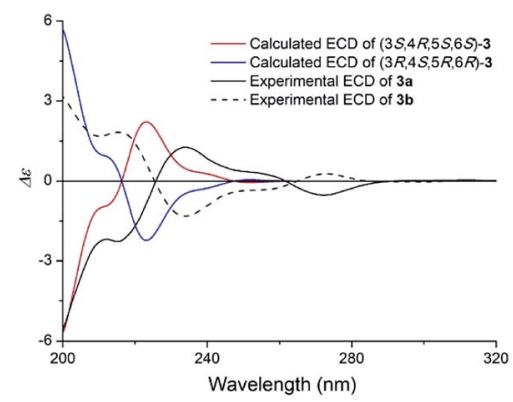

Fig. 9 Calculated ECD spectra of $(3 S, 4 R, 5 S, 6 S)-3$ and $(3 R, 4 S, 5 R, 6 R)-3$ and the experimental ECD spectra of (+)- and (-)-clauselansine $C(3 \mathrm{a} /$ 3b) in $\mathrm{MeOH}$.
Table $3{ }^{1} \mathrm{H}$ and ${ }^{13} \mathrm{C}$ NMR spectroscopic data of compounds $4 \mathrm{a}$ and $5 \mathrm{a}$ ( $\delta$ in ppm, $J$ in $\mathrm{Hz}$ )

\begin{tabular}{|c|c|c|c|c|}
\hline \multirow[b]{2}{*}{ Position } & \multicolumn{2}{|l|}{$4 a$} & \multicolumn{2}{|l|}{$5 a$} \\
\hline & $\delta_{\mathrm{H}}{ }^{a}$ & $\delta_{\mathrm{C}}^{b}$ & $\delta_{\mathrm{H}}^{a}$ & $\delta_{\mathrm{C}}^{b}$ \\
\hline 1 & & 144.3 & & 138.6 \\
\hline $1 \mathrm{a}$ & & $132.6 \mathrm{~s}$ & & 136.3 \\
\hline 2 & & $123.2 \mathrm{~s}$ & & 135.1 \\
\hline 3 & & $129.1 \mathrm{~s}$ & & 118.8 \\
\hline 4 & $7.62, \mathrm{~s}$ & $111.2 \mathrm{~s}$ & $8.37, \mathrm{~s}$ & 112.7 \\
\hline $4 a$ & & $122.7 \mathrm{~d}$ & & 122.6 \\
\hline 5 & $8.04, \mathrm{~d}(7.5)$ & $120.1 \mathrm{~d}$ & $8.27, \mathrm{~d}(7.5)$ & 121.0 \\
\hline $5 a$ & & 123.6 & & 126.3 \\
\hline 6 & $7.14, \mathrm{t}(7.5)$ & 118.8 & $7.22, \mathrm{t}(7.5)$ & 119.6 \\
\hline 7 & $7.38, \mathrm{t}(7.5)$ & 125.8 & $7.46, \mathrm{t}(7.5)$ & 126.7 \\
\hline 8 & $7.50, \mathrm{t}(7.5)$ & 111.4 & $7.55, \mathrm{~d}(7.5)$ & 111.7 \\
\hline $8 \mathrm{a}$ & & 140.1 & & 140.8 \\
\hline $1^{\prime}$ & $4.77, \mathrm{~d}(7.5)$ & 61.2 & $6.16, \mathrm{~s}$ & 77.6 \\
\hline $2^{\prime}$ & $4.30, \mathrm{~s}$ & 86.0 & $3.89, \mathrm{~d}(7.5)$ & 75.8 \\
\hline $3^{\prime}$ & & 76.9 & & 71.6 \\
\hline $4^{\prime}$ & $1.27, \mathrm{~s}$ & 29.7 & $1.22, \mathrm{~s}$ & 28.5 \\
\hline $5^{\prime}$ & $1.04, \mathrm{~s}$ & 23.2 & $1.26, \mathrm{~s}$ & 24.7 \\
\hline $6^{\prime}$ & $6.09, \mathrm{~s}$ & 100.3 & & 170.8 \\
\hline $1-\mathrm{OCH}_{3}$ & $3.91, \mathrm{~s}$ & 61.0 & $4.06, \mathrm{~s}$ & 60.3 \\
\hline $\mathrm{NH}$ & 11.37 , br s & & $11.80 \mathrm{br} \mathrm{s}$ & \\
\hline $1^{\prime}-\mathrm{OH}$ & $5.34, \mathrm{~d}(7.5)$ & & & \\
\hline $2^{\prime}-\mathrm{OH}$ & & & $5.71, \mathrm{~d}(6.0)$ & \\
\hline
\end{tabular}

${ }^{a}$ In DMSO- $d_{6}(600 \mathrm{MHz}) .{ }^{b}$ In DMSO- $d_{6}(150 \mathrm{MHz})$. Coupling constants $(J)$ in $\mathrm{Hz}$ are given in parentheses. The assignments were based on HSQC and HMBC experiments.

comparison of the calculated ECD spectra of the $1^{\prime} R, 2^{\prime} R, 6^{\prime} R$ and $1^{\prime} S, 2^{\prime} S, 6^{\prime} S$ configurations of 4 with the experimental data of $4 a$ and $\mathbf{4 b}$ (Fig. 10), the absolute configurations of $\mathbf{4 a}$ and $\mathbf{4 b}$ were assigned as $1^{\prime} R, 2^{\prime} R, 6^{\prime} R$ and $1^{\prime} S, 2^{\prime} S, 6^{\prime} S$. Thus, 4 a was defined as $(+)-\left(1^{\prime} R, 2^{\prime} R, 6^{\prime} R\right)$-claulansine $\mathrm{B}$, and $\mathbf{4} \mathbf{b}$ was identified as the known compound $(-)-\left(1^{\prime} S, 2^{\prime} S, 6^{\prime} S\right)$-claulansine B.

Compound $5(\mathbf{5 a} / \mathbf{5 b})$ was obtained as a white powder. The HRESIMS displayed $\mathrm{m} / z 364.1163[\mathrm{M}+\mathrm{Na}]^{+}$(calcd for $\mathrm{C}_{19} \mathrm{H}_{19} \mathrm{NO}_{5} \mathrm{Na}$ 364.1155), which was consistent with a molecular formula of $\mathrm{C}_{19} \mathrm{H}_{19} \mathrm{NO}_{5}$ with eleven indices of hydrogen deficiency. Its NMR data (Table 3) was almost identical to those of claulansine D. ${ }^{10}$ Chiral isolation of $\mathbf{5}$ afforded the enantiomer $\mathbf{5 a}$ $\left\{[\alpha]_{\mathrm{D}}^{20}+62.0(c 0.11 \mathrm{MeOH})\right\}$ and $5 \mathbf{b}\left\{[\alpha]_{\mathrm{D}}^{20}-99.2(c 0.1 \mathrm{MeOH})\right\}$,

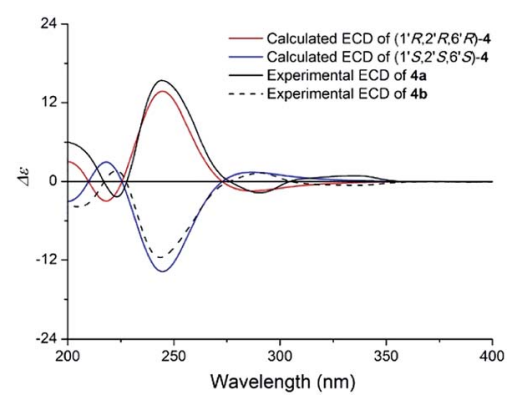

Fig. 10 Calculated ECD spectra of $\left(1^{\prime} R, 2^{\prime} R, 6^{\prime} R\right)-4$ and $\left(1^{\prime} S, 2^{\prime} S, 6^{\prime} S\right)-4$ and the experimental ECD spectra of $(+)$ - and $(-)$-claulansine $B$ $(4 a / 4 b)$ in $\mathrm{MeOH}$. 
which had opposite ECD curves (Fig. 11). The absolute configurations of $\mathbf{5 a}$ and $\mathbf{5 b}$ were determined using the same methods as described in $\mathbf{4 a}$ and $\mathbf{4 b}$. Thus, 5a was defined as $(+)-\left(1^{\prime} R, 2^{\prime} R\right)-$ claulansine $\mathrm{D}$, and $\mathbf{5 b}$ was identified as the known compound $(-)-\left(1^{\prime} S, 2^{\prime} S\right)$-claulansine D.

The structures of nine known compounds were also identified by comparing their spectroscopic data to those found in the literature. The known compounds isolated were claulansine B (4b) ${ }^{\mathbf{1 0}}$ claulansine $\mathrm{D}(\mathbf{5 b}),{ }^{\mathbf{1 0}}(-)-(1 S, 3 S)-1$-methyl-1,2,3,4-tetrahydro- $\beta$-carboline-3-carboxylic acid $(6 \mathbf{6 a}){ }^{28}(+)-(1 R, 3 S)-1-$ methyl1,2,3,4-tetrahydro- $\beta$-carboline-3-carboxylic acid $(\mathbf{6 b}),^{28}(R)$-isoplatydesmine $(\mathbf{7 a}),{ }^{29}(S)$-isoplatydesmine $(\mathbf{7 b}),{ }^{\mathbf{3 0}}$ claulansine $\mathbf{A}$ $(8),{ }^{10}$ ribalinine $(9),{ }^{31} \gamma$-fagarine $(\mathbf{1 0}),{ }^{32}$ dictamnine $(\mathbf{1 1}),{ }^{33} \mathrm{~N}-(2$ hydroxy-2-phenylethyl)-cinnamamide (12), ${ }^{34} \quad \mathrm{~N}$-phenylethylbenzamide $(13) .^{34}$

Compounds 1-13 were evaluated for their neuroprotective effect on neuron-like PC12 cells induced by $\mathrm{A} \beta_{25-35}$, and Okadaic Acid (OKA) in vitro using the MTT method. The neuron growth factor (NGF) was used as a positive control. At $10 \mu \mathrm{M}, \mathbf{1 b}, \mathbf{2 a}, \mathbf{3 b}$, $\mathbf{5 a}, \mathbf{5 b}$ increased the cell survival rate of the Okadaic acid-treated group, other compounds were inactive, while all the compounds failed to protect cells from $A \beta_{25-35}$.

Clausenamide is one of novel compounds isolated from Clausena lansium (Lour) skeels. Clausenamide is unusual in that it contains 4 chiral centers yielding 8 pairs of enantiomers. In

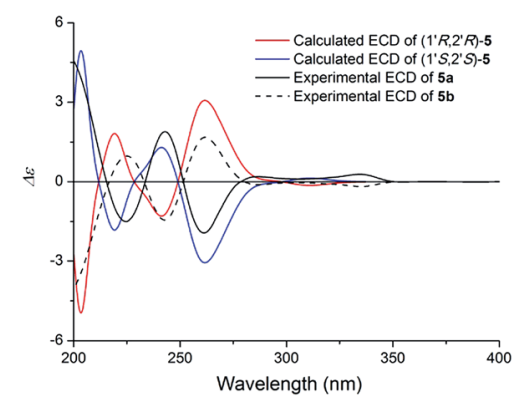

Fig. 11 Calculated ECD spectra of $\left(1^{\prime} R, 2^{\prime} R\right)-5$ and $\left(1^{\prime} S, 2^{\prime} S\right)-5$ and the experimental ECD spectra of $(+)$ - and $(-)$-claulansine $D(5 a / 5 b)$ in $\mathrm{MeOH}$.

Table 4 Neuroprotective effects of compounds 1-13 against Okadaic acid-induced injury in PC12 Cells $(10 \mu \mathrm{M} \text {, means } \pm \mathrm{SD}, n=6)^{a}$

\begin{tabular}{|c|c|c|}
\hline Control & $10 \mu \mathrm{M}$ & $100.0 \pm 2.64$ \\
\hline Model & $10 \mu \mathrm{M}$ & $70.5 \pm 5.4^{\# \# \# ~}$ \\
\hline 1a & $10 \mu \mathrm{M}$ & $65.4 \pm 6.2$ \\
\hline $1 \mathrm{~b}$ & $10 \mu \mathrm{M}$ & $83.4 \pm 4.1^{* *}$ \\
\hline $2 a$ & $10 \mu \mathrm{M}$ & $91.2 \pm 10.1^{* * *}$ \\
\hline $2 b$ & $10 \mu \mathrm{M}$ & $69.5 \pm 5.3$ \\
\hline $3 a$ & $10 \mu \mathrm{M}$ & $71.7 \pm 5.9$ \\
\hline $3 \mathbf{b}$ & $10 \mu \mathrm{M}$ & $83.5 \pm 7.8^{* *}$ \\
\hline $4 a$ & $10 \mu \mathrm{M}$ & $74.4 \pm 4.6$ \\
\hline $4 b$ & $10 \mu \mathrm{M}$ & $76.6 \pm 7.5$ \\
\hline $5 a$ & $10 \mu \mathrm{M}$ & $89.7 \pm 4.8^{* * *}$ \\
\hline $5 \mathbf{b}$ & $10 \mu \mathrm{M}$ & $83.3 \pm 5.9^{* * *}$ \\
\hline
\end{tabular}

pharmacological studies numerous models and indicators showed that (-)-clausenamide is the active enantiomer, while $(+)$-clausenamide is inactive and elicits greater toxicity than (-)-clausenamide. ${ }^{35}$ Compounds 3 and clausenamide are very similar in structure and therefore have the same biological activity. Similarly, $\mathbf{3 b}$ is the active enantiomer, while $\mathbf{3 a}$ is inactive. The carbazole and quinolone alkaloids having neuroprotective effects were exhibited in previous researches, ${ }^{\mathbf{1 0}, 36}$ and carbazole alkaloids may derived from indole alkaloids. As we all know, thalidomide as a chiral racemic compound, its $R$-configuration has inhibitory activity of pregnancy, while $S$-configuration has teratogenic. One of the isomers of the enantiomer is highly active and the other isomer is inactive, or both isomers are active, or both isomers are inactive. Thus, it's reasonable that compound $\mathbf{1 b}, \mathbf{2 a}, \mathbf{5 a}$, and $\mathbf{5 b}$ are active while $\mathbf{1 a}$, $\mathbf{2 b}$ are inactive. All in all, alkaloids isolated from $C$. lansium are worthy of study to find more potential effects in the further (Table 4).

\section{Conclusions}

In summary, we have reported the isolation, identification and biological study of twenty compounds (1-13) including three new enantiomers (1a, 1b, 2a, 2b, 3a, 3b), two new ones (4a, 5a), and several of them inhibited PC12 cell damage induced by Okadaic Acid. Furthermore, compounds 6-7 were isolated from the genus Clausena for the first time. The occurrence of alkaloids derivatives from $C$. lansium is in agreement with the previous findings, 1-7 indicating that the isolation of these enantiomer compounds might be a useful chemotaxonomic for screening activity. The results of preliminary neuroprotective effect assays suggested that several isolated alkaloids derivatives showed moderate activity. Moreover, previous findings exhibited that the carbazole, amide and quinolone alkaloids metabolites have neuroprotective effects and others biological activities such as anti-inflammatory, hepatoprotective, cytotoxic $\mathrm{c}^{\mathbf{9 1 5 - 1 7}}$ which indicating that the alkaloid compounds and their biological activities of $C$. lansium are worth studying in order to find compounds with potential activity.

\section{Experimental}

Optical rotations were measured on a JASCO P2000 automatic digital polarimeter. UV spectra were recorded on a JASCO V-650 spectrophotometer, CD spectra were measured on a JASCO J815 spectropolarimeter. IR spectra were recorded on a Nicolet 5700 spectrometer using an FT-IR microscope transmission method. NMR spectra were acquired with Bruker AVIIIHD 600, VNS-600, and Mercury-400 spectrometers in DMSO- $d_{6}$ and MeOH- $d_{6}$. HRESIMS spectra were collected on an Agilent 1100 series LC/MSD ion trap mass spectrometer. MPLC system was composed of two C-605 pumps (Büchi), a C-635 UV detector (Büchi), a C-660 fraction collector (Büchi), and an ODS column (450 mm $\times 60 \mathrm{~mm}, 50 \mu \mathrm{m}, 400 \mathrm{~g}$; YMC). Semi-preparative HPLC was conducted using a Shimadzu LC-6AD instrument with an SPD-20A detector and a Daicel Chiralpak AD-H column $(250 \times$ $10 \mathrm{~mm}, 5 \mu \mathrm{m})$. Preparative HPLC was also performed on 
a Shimadzu LC-6AD instrument with a YMC-Pack ODS-A column $(250 \times 20 \mathrm{~mm}, 5 \mu \mathrm{m})$. Column chromatography (CC) was performed with silica gel (200-300 mesh, Qingdao Marine Chemical Inc., Qingdao, People's Republic of China), SF-PRP 512A (100-200 mesh, Beijing Sunflower and Technology Development Co., Beijing, People's Republic of China), ODS (50 $\mu \mathrm{m}$, YMC, Japan), and Sephadex LH-20 (GE, Sweden). TLC was carried out on glass precoated silica gel GF254 plates. Spots were visualized under UV light or by spraying with $10 \%$ sulfuric acid in EtOH followed by heating. PC12 cells (adrenal gland; pheochromocytoma) were purchased from the American Type Culture Collection. Dimethyl sulphoxide (DMSO), $\mathrm{A} \beta_{25-35}$, Okadaic acid, 3-(3,4-dimethylthiazol-2-yl)-2,5-diphenyltetrazolium bromide (MTT) were obtained from Sigma (St Louis, MO, USA). Dulbecco's Modified Eagle's Medium (DMEM), fetal bovine serum (FBS) and equine serum were purchased from Gibco BRL (New York, NY, USA). All other chemicals were of analytical grade and were commercially available.

\section{Plant material}

The stems of $C$. lansium were collected in Liuzhou, Guangxi, China, in December 2008 and identified by Engineer Guangri Long, Forestry of Liuzhou. A voucher specimen has been deposited at the Herbarium of Institute of Materia Medica, Chinese Academy of Medical Sciences \& Peking Union Medical College (ID-S-2320).

Extraction and isolation. Air-dried, powdered stems of C. lansium ( $200 \mathrm{~kg}$ ) were macerated for $3 \mathrm{~h}$ with $20 \mathrm{~L}$ of $95 \%$ $\mathrm{EtOH}(\mathrm{aq})$ and refluxed for $4 \mathrm{~h}(20 \mathrm{~L} \times 2)$. The filtrate was evaporated under reduced pressure to yield a dark brown residue $(640 \mathrm{~g})$. The residue was suspended in water $(2000 \mathrm{~mL})$ and then partitioned with $\mathrm{CHCl}_{3}(3 \times 2000 \mathrm{~mL})$, EtOAc $(3 \times$ $2000 \mathrm{~mL})$, and $n$-BuOH $(3 \times 2000 \mathrm{~mL})$, successively. After removing the solvent, the $n$-BuOH-soluble portion (850 g) was fractionated via macroporous adsorbent resin (HPD-100) column with $\mathrm{H}_{2} \mathrm{O}, 30 \%$ EtOH, 60\% EtOH, and 95\% EtOH to yield four corresponding fractions A-D.

Fraction B (180.6 g) was fractionated via silica gel column chromatography, eluting with $\mathrm{CHCl}_{3}-\mathrm{MeOH}-\mathrm{H}_{2} \mathrm{O}(10: 1: 0.05$, $9: 1: 0.1,8: 2: 0.2,7: 3: 0.3,6: 4: 0.4)$ to afford twelve fractions $\mathrm{B}_{1}-\mathrm{B}_{12}$ on the basis of TLC analysis. Fraction $\mathrm{B}_{4}(5.9 \mathrm{~g})$ was further separated by reversed-phase silica MPLC with $\mathrm{MeOH}-$ $\mathrm{H}_{2} \mathrm{O}\left(20-50 \%, 50 \mathrm{~mL} \min ^{-1}, 6 \mathrm{~h}\right)$ to afford $\mathrm{B}_{4-1}-\mathrm{B}_{4-47}$ fractions. Fractions $\mathrm{B}_{4-38}-\mathrm{B}_{4-42}$ was successively separated using preparative HPLC (detection at $210 \mathrm{~nm}, 18 \% \mathrm{CH}_{3} \mathrm{CN}, 8 \mathrm{~mL} \mathrm{~min}{ }^{-1}$ ) to yield 1 (20.3 mg, $\left.t_{\mathrm{R}} 37.50 \mathrm{~min}\right)$. Compound 1 was further separated by semipreparative chiral HPLC ( $n$-hexane-2-propanol, $\left.6: 1,3 \mathrm{~mL} \mathrm{~min}^{-1}\right)$ to give $\mathbf{1 a}\left(9.1 \mathrm{mg}, t_{\mathrm{R}} 57.63 \mathrm{~min}\right)$ and $\mathbf{1 b}$ $\left(8.7 \mathrm{mg}, t_{\mathrm{R}} 67.99 \mathrm{~min}\right)$. Fraction $\mathrm{B}_{10}(5.1 \mathrm{~g})$ was further separated by reversed-phase silica MPLC with $\mathrm{MeOH}-\mathrm{H}_{2} \mathrm{O}(20-50 \%$, $50 \mathrm{~mL} \min ^{-1}, 7 \mathrm{~h}$ ) to afford $\mathrm{B}_{10-1}-\mathrm{B}_{10-65}$ fractions. Fractions $\mathrm{B}_{10-15}-\mathrm{B}_{10-20}$ were successively separated using preparative HPLC (detection at $210 \mathrm{~nm}, 8 \% \mathrm{CH}_{3} \mathrm{CN}, 8 \mathrm{~mL} \mathrm{~min}^{-1}$ ) to yield 6 a $\left(8.2 \mathrm{mg}, t_{\mathrm{R}} 58.35 \mathrm{~min}\right)$ and $6 \mathrm{~b}\left(2.4 \mathrm{mg}, t_{\mathrm{R}} 68.93 \mathrm{~min}\right)$.

Fraction C (197.3 g) was fractionated via silica gel column chromatography, eluting with $\mathrm{CHCl}_{3}$, EtOAc, $n$-BuOH,
$\mathrm{CH}_{3} \mathrm{COCH}_{3}, \mathrm{MeOH}$ to afford five fractions $\mathrm{C}_{1}-\mathrm{C}_{5}$. Fraction $\mathrm{C}_{1}$ was further separated by PRP-512A with $\mathrm{MeOH}-\mathrm{H}_{2} \mathrm{O}(35-70 \%)$ to afford $\mathrm{C}_{1-1}-\mathrm{C}_{1-6}$ fractions. Fraction $\mathrm{C}_{1-3}$ was further separated by reversed-phase silica MPLC with $\mathrm{MeOH}-\mathrm{H}_{2} \mathrm{O}(35-55 \%, 50$ $\mathrm{mL} \min ^{-1}, 6 \mathrm{~h}$ ) to afford $\mathrm{C}_{1-3-1}-\mathrm{C}_{1-3-12}$ fractions. Fraction $\mathrm{C}_{1-3-11}$ was successively separated by Sephadex LH-20 and then using preparative HPLC (detection at $210 \mathrm{~nm}, 30 \% \mathrm{CH}_{3} \mathrm{CN}, 8 \mathrm{~mL}$ $\left.\min ^{-1}\right)$ to yield $5\left(6.2 \mathrm{mg}, t_{\mathrm{R}} 42.87 \mathrm{~min}\right), 7\left(11.2 \mathrm{mg}, t_{\mathrm{R}} 62.14\right.$ $\min )$ and $9\left(24.4 \mathrm{mg}, t_{\mathrm{R}} 51.17 \mathrm{~min}\right)$. Compound 5 was further separated by semipreparative chiral HPLC ( $n$-hexane-2propanol, $\left.3: 1,3 \mathrm{~mL} \mathrm{~min}^{-1}\right)$ to give $5 \mathrm{a}\left(2.8 \mathrm{mg}, t_{\mathrm{R}} 36.37 \mathrm{~min}\right.$ ) and $\mathbf{5 b}\left(2.1 \mathrm{mg}, t_{\mathrm{R}} 45.78 \mathrm{~min}\right)$. Compound 7 was further separated by semipreparative chiral HPLC ( $n$-hexane-2-propanol, $\left.7: 1,3 \mathrm{~mL} \min ^{-1}\right)$ to give $7 \mathbf{a}\left(4.8 \mathrm{mg}, t_{\mathrm{R}} 19.85 \mathrm{~min}\right)$ and $7 \mathbf{b}$ (5.3 $\left.\mathrm{mg}, t_{\mathrm{R}} 25.86 \mathrm{~min}\right)$. Fraction $\mathrm{C}_{1-3-12}$ was successively separated by Sephadex LH-20 and then using preparative HPLC (detection at $210 \mathrm{~nm}, 29 \% \mathrm{CH}_{3} \mathrm{CN}, 8 \mathrm{~mL} \mathrm{~min}{ }^{-1}$ ) to yield 2 $\left(5.2 \mathrm{mg}, t_{\mathrm{R}} 48.14 \mathrm{~min}\right)$. Compound 2 was further separated by semipreparative chiral HPLC ( $n$-hexane-2-propanol, $8: 1,3 \mathrm{~mL}$ $\left.\mathrm{min}^{-1}\right)$ to give $2 \mathrm{a}\left(2.8 \mathrm{mg}, t_{\mathrm{R}} 25.81 \mathrm{~min}\right)$ and $2 \mathrm{~b}\left(2.1 \mathrm{mg}, t_{\mathrm{R}} 34.17\right.$ min). Fraction $\mathrm{C}_{1-5}$ was further separated by reversed-phase silica MPLC with $\mathrm{MeOH}-\mathrm{H}_{2} \mathrm{O}\left(35-55 \%, 50 \mathrm{~mL} \min ^{-1}, 6 \mathrm{~h}\right)$ to afford $\mathrm{C}_{1-5-1}-\mathrm{C}_{1-5-8}$ fractions. Fraction $\mathrm{C}_{1-5-6}$ was successively separated via silica gel column chromatography and then using preparative HPLC (detection at $210 \mathrm{~nm}, 32 \% \mathrm{CH}_{3} \mathrm{CN}, 8 \mathrm{~mL}$ $\left.\min ^{-1}\right)$ to yield $3\left(10.7 \mathrm{mg}, t_{\mathrm{R}} 53.75 \mathrm{~min}\right), 4\left(9.2 \mathrm{mg}, t_{\mathrm{R}} 39.05\right.$ $\min ), 10$ (3.1 mg, $\left.t_{\mathrm{R}} 52.10 \mathrm{~min}\right), 12\left(2.4 \mathrm{mg}, t_{\mathrm{R}} 49.16 \mathrm{~min}\right)$ and 13 (3.2 $\mathrm{mg}, t_{\mathrm{R}} 65.64 \mathrm{~min}$ ). Compound 3 was further separated by semipreparative chiral HPLC ( $n$-hexane-2-propanol, $9: 1,3 \mathrm{~mL}$ $\left.\mathrm{min}^{-1}\right)$ to give $3 \mathrm{a}\left(4.1 \mathrm{mg}, t_{\mathrm{R}} 19.87 \mathrm{~min}\right)$ and $3 \mathrm{~b}\left(3.9 \mathrm{mg}, t_{\mathrm{R}} 25.12\right.$ min). Compound 4 was further separated by semipreparative chiral HPLC ( $n$-hexane-2-propanol, $7: 1,3 \mathrm{~mL} \mathrm{~min}^{-1}$ ) to give 4a $\left(1.5 \mathrm{mg}, t_{\mathrm{R}} 21.98 \mathrm{~min}\right)$ and $4 \mathrm{~b}\left(4.3 \mathrm{mg}, t_{\mathrm{R}} 40.07 \mathrm{~min}\right)$. Fraction $\mathrm{C}_{1-}$ 6 was further separated by reversed-phase silica MPLC with $\mathrm{MeOH}-\mathrm{H}_{2} \mathrm{O}\left(35-55 \%, 50 \mathrm{~mL} \mathrm{~min}^{-1}, 6 \mathrm{~h}\right)$ to afford $\mathrm{C}_{1-6-1}-\mathrm{C}_{1-6-10}$ fractions. Fraction $\mathrm{C}_{1-6-2}$ was successively separated via silica gel column chromatography and then using preparative HPLC (detection at $210 \mathrm{~nm}, 30 \% \mathrm{CH}_{3} \mathrm{CN}, 8 \mathrm{~mL} \mathrm{~min}{ }^{-1}$ ) to yield 8 $\left(5.2 \mathrm{mg}, t_{\mathrm{R}} 33.31 \mathrm{~min}\right)$ and $11\left(7.1 \mathrm{mg}, t_{\mathrm{R}} 23.17 \mathrm{~min}\right)$.

$(+)-\left(2^{\prime} S, 3^{\prime} R\right)$-Clauselansine A (1a). Colourless oil; $[\alpha]_{\mathrm{D}}^{20}+18.7$ (c $0.1 \mathrm{MeOH}) ; \mathrm{UV}(\mathrm{MeOH}) \lambda_{\max }(\log \varepsilon) 202.8$ (4.29), 222.6 (4.38), 281.8 (3.48) nm; ECD $(\mathrm{MeOH}) \lambda_{\max }(\Delta \varepsilon) 268(+0.75), 226$ (+4.01) nm; IR (microscope) $\nu_{\max } 3313,2925,1671,1612,1439$, 1379, 1109, 1040, $749 \mathrm{~cm}^{-1} ;{ }^{1} \mathrm{H}$ NMR (DMSO- $d_{6}, 400 \mathrm{MHz}$ ) and ${ }^{13} \mathrm{C}$ NMR (DMSO- $d_{6}, 100 \mathrm{MHz}$ ), see Table 1 ; HRESIMS $\mathrm{m} / \mathrm{z}$ $320.1854[\mathrm{M}+\mathrm{H}]^{+}$(calcd for $\mathrm{C}_{18} \mathrm{H}_{26} \mathrm{NO}_{4}, 320.1856$ ).

$(-)-\left(2^{\prime} R, 3^{\prime} S\right)$-Clauselansine $A(\mathbf{1 b})$. Colourless oil; $[\alpha]_{\mathrm{D}}^{20}-17.0$ (c $0.1 \mathrm{MeOH}) ; \mathrm{ECD}(\mathrm{MeOH}) \lambda_{\max }(\Delta \varepsilon) 268$ (-0.23), 226 $(-0.79) \mathrm{nm}$; UV, IR, NMR, and HRESIMS were the same as those of 1 a.

$(+)-\left(2^{\prime} S, 3^{\prime} R\right)$-Clauselansine $B(2 a)$. White powder; $[\alpha]_{\mathrm{D}}^{20}+28.0$ (c $0.1 \mathrm{MeOH})$; UV (MeOH) $\lambda_{\max }(\log \varepsilon) 203.0$ (4.37), 220.0 (4.37), 281.6 (3.53) nm; ECD $(\mathrm{MeOH}) \lambda_{\max }(\Delta \varepsilon) 276(-0.18), 233$ (+1.03) nm; IR (microscope) $\nu_{\max } 3358,2917,2851,1615,1377$, 1039, 1002, $739 \mathrm{~cm}^{-1}$; ${ }^{1} \mathrm{H}$ NMR (DMSO- $d_{6}, 600 \mathrm{MHz}$ ) and ${ }^{13} \mathrm{C}$ NMR (DMSO- $d_{6}, 150 \mathrm{MHz}$ ), see Table 1; HRESIMS $m / z 302.1758$ $[\mathrm{M}+\mathrm{H}]^{+}$(calcd for $\mathrm{C}_{18} \mathrm{H}_{24} \mathrm{NO}_{3}, 302.1751$ ). 
$(-)-\left(2^{\prime} R, 3^{\prime} S\right)$-Clauselansine $B(\mathbf{2 b})$. White powder; $[\alpha]_{\mathrm{D}}^{20}-32.6$

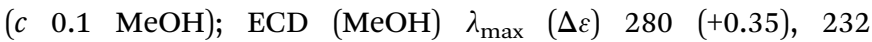
$(-1.56) \mathrm{nm}$; UV, IR, NMR, and HRESIMS were the same as those of $2 \mathrm{a}$.

(+)-(3S,4R,5S,6S)-Clauselansine $C \quad(3 a)$. White powder;

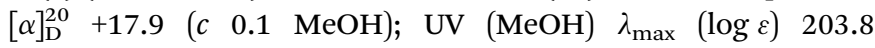
(4.28) nm; ECD (MeOH) $\lambda_{\max }(\Delta \varepsilon) 272(-0.53), 234(+1.27), 215$ $(-2.27) \mathrm{nm}$; IR (microscope) $\nu_{\max } 3320,2923,1678,1483,1454$, 1403, 1202, 1132, 1078, 753, $703 \mathrm{~cm}^{-1}$; ${ }^{1} \mathrm{H}$ NMR (DMSO- $d_{6}, 400$ $\mathrm{MHz}$ ) and ${ }^{13} \mathrm{C}$ NMR (DMSO- $d_{6}, 100 \mathrm{MHz}$ ), see Table 2; HRESIMS $m / z 280.1333[\mathrm{M}+\mathrm{Na}]^{+}$(calcd for $\mathrm{C}_{18} \mathrm{H}_{17} \mathrm{NaNO}_{2}, 280.1332$ ).

(-)-(3R,4S,5R,6R)-Clauselansine $C$ (3b). White powder; $[\alpha]_{\mathrm{D}}^{20}-22.0(c 0.1 \mathrm{MeOH}) ; \mathrm{ECD}(\mathrm{MeOH}) \lambda_{\max }(\Delta \varepsilon) 272(+0.27), 234$ $(-1.31), 215(+1.84) \mathrm{nm}$; UV, IR, NMR, and HRESIMS were the same as those of $\mathbf{3 a}$.

$(+)-\left(1^{\prime} R, 2^{\prime} R, 6^{\prime} R\right)$-Claulansine $B \quad(\mathbf{4 a})$. White powder; $[\alpha]_{\mathrm{D}}^{20}+142.7(c 0.1 \mathrm{MeOH}) ; \mathrm{UV}(\mathrm{MeOH}) \lambda_{\max }(\log \varepsilon) 201.6(4.40)$, 241.8 (4.24), 294.8 (3.68) nm; ECD (MeOH) $\lambda_{\max }(\Delta \varepsilon) 335(+0.90)$, $290(-1.71), 244(+15.40), 223(-2.31) \mathrm{nm}$; IR (microscope) $\nu_{\max }$ 3319, 2971, 1613, 1573, 1503, 1456, 1383, 1248, 1081, 1024, 745 $\mathrm{cm}^{-1} ;{ }^{1} \mathrm{H}$ NMR (DMSO- $d_{6}, 600 \mathrm{MHz}$ ) and ${ }^{13} \mathrm{C}$ NMR (DMSO- $d_{6}$, $150 \mathrm{MHz}$ ), see Table 3; HRESIMS $m / z 326.1398[\mathrm{M}+\mathrm{H}]^{+}$(calcd for $\left.\mathrm{C}_{19} \mathrm{H}_{20} \mathrm{NO}_{4}, 326.1387\right)$.

$(+)-\left(1^{\prime} R, 2^{\prime} R\right)$-Claulansine $D(5 \boldsymbol{a})$. White powder; $[\alpha]_{\mathrm{D}}^{20}+62.0(c$ $0.11 \mathrm{MeOH})$; UV (MeOH) $\lambda_{\max }(\log \varepsilon) 195.8$ (3.71), 231.0 (3.87), 278.2 (4.11) nm; ECD (MeOH) $\lambda_{\max }(\Delta \varepsilon) 335(+0.28), 261(-1.94)$, 243 (+1.89), 225 (-1.50) nm; IR (microscope) $\nu_{\max } 3379,2919$, 2850, 1737, 1613, 1462, 1358, 1242, 1099, $729 \mathrm{~cm}^{-1} ;{ }^{1} \mathrm{H}$ NMR (DMSO- $d_{6}, 600 \mathrm{MHz}$ ) and ${ }^{13} \mathrm{C}$ NMR (DMSO- $d_{6}, 150 \mathrm{MHz}$ ), see Table 3; HRESIMS $m / z$ 364.1163 $[\mathrm{M}+\mathrm{Na}]^{+}$(calcd for $\left.\mathrm{C}_{19} \mathrm{H}_{19} \mathrm{NNaO}_{5}, 364.1155\right)$.

\section{Preparation of acetonide derivative (1c)}

To determine the relative configuration of $\mathbf{1 b}$, compound $\mathbf{1 b}$ ( 3 $\mathrm{mg}$ ) was treated with 2,2-dimethoxypropane $(1 \mathrm{~mL})$ and pyridinium $p$-toluene sulfonate $(1 \mathrm{mg})$, then stirred at $30^{\circ} \mathrm{C}$ for $5 \mathrm{~h}$ under $\mathrm{N}_{2}$ circumstance. The reaction solution was evaporated in vacuo and purified by reversed-phase preparative HPLC using $\mathrm{CH}_{3} \mathrm{OH} / \mathrm{H}_{2} \mathrm{O}(60: 40 \mathrm{v} / \mathrm{v})$ to yield the acetonide $1 \mathrm{c}(2.47 \mathrm{mg})$.

Compound 1c. White amorphous powder; $[\alpha]_{\mathrm{D}}^{20}+12.0(c 0.2$ $\mathrm{MeOH}) ; \mathrm{UV}(\mathrm{MeOH}) \lambda_{\max }(\log \varepsilon) 206$ (6.24), 225 (6.40), 277 (5.75) nm; ECD (MeOH) $\lambda_{\max }(\Delta \varepsilon) 267$ (-1.28), 251 (-0.78), 234 $(-2.14) \mathrm{nm} ; \mathrm{Mo}_{2}(\mathrm{OAc})_{4}$-induced CD (DMSO) $323(\Delta \varepsilon+0.26) \mathrm{nm}$; IR (microscope) $\nu_{\max } 3307,2923,2854,1645,1542,1452,1400$, 1240, 1099, $660 \mathrm{~cm}^{-1}$; ${ }^{1} \mathrm{H}$ NMR (DMSO- $d_{6}, 600 \mathrm{MHz}$ ) and ${ }^{13} \mathrm{C}$ NMR (DMSO- $d_{6}, 150 \mathrm{MHz}$ ), see Table 1; HRESIMS $m / z 382.1993$ $[\mathrm{M}+\mathrm{Na}]^{+}$(calcd for $\mathrm{C}_{21} \mathrm{H}_{29} \mathrm{NNaO}_{4}, 382.1989$ ).

\section{Determination of absolute configurations of the $3^{\prime}, 4^{\prime}$-diol unit in $1 \mathrm{c}$}

According to the published procedure, a $1: 1.2$ mixture of diol/ $\mathrm{Mo}_{2}(\mathrm{OAc})_{4}$ for 1c was subjected to $\mathrm{CD}$ measurements at a concentration of $0.1 \mathrm{mg} \mathrm{mL}^{-1}$ in anhydrous DMSO. The first CD spectrum was recorded immediately after mixing, and its time evolution was monitored until stationary (about $10 \mathrm{~min}$ after mixing). The inherent $\mathrm{CD}$ was subtracted. The observed sign of the diagnostic band at around $310 \mathrm{~nm}$ in the induced CD spectrum was correlated to the absolute configuration of the $3^{\prime}, 4^{\prime}$-diol unit.

\section{Preparation of $(R)$ - and $(S)$-MTPA eaters of 3a}

A solution of 3a $(1.31 \mathrm{mg})$ in dehydrated $\mathrm{CH}_{2} \mathrm{Cl}_{2}(2 \mathrm{~mL})$ was treated with $(R)-(+)-\alpha$-methoxy- $\alpha$-(trifluoromethyl)phenylacetyl chloride $[(R)$-MTPA-Cl $(10 \mathrm{mg})]$ in the presence of anhydrous pyridine, and the mixture was stirred at room temperature for $13 \mathrm{~h}$. After cooling, the reaction mixture was poured into icewater and extracted with EtOAC. The EtOAC extract was successively washed with $5 \%$ aqueous $\mathrm{HCl}$, saturated aqueous $\mathrm{NaHCO}_{3}$, and brine, then dried over $\mathrm{Na}_{2} \mathrm{SO}_{4}$ and filtered. The solvent was removed from the filtrate under reduced pressure to afford a residue. The residue was purified by semi-preparative HPLC (C18 column, $3.0 \mathrm{~mL} \mathrm{~min}^{-1}$, UV $210 \mathrm{~nm}, 80 \% \mathrm{CH}_{3} \mathrm{CN}-$ $\mathrm{H}_{2} \mathrm{O}$ ) to yield $(S)$-MTPA ester derivative of 3a (compound 3aa $1.03 \mathrm{mg}$ ). (R)-MTPA ester derivative of 3a (compound 3ab 0.92 $\mathrm{mg})$ was obtained from $3 \mathrm{a}(1.05 \mathrm{mg})$.

Compound 3aa. Colourless oil; ${ }^{1} \mathrm{H}$ NMR (600 $\left.\mathrm{MHz}, \mathrm{CDCl}_{3}\right) \delta_{\mathrm{H}}$ $5.73(1 \mathrm{H}, \mathrm{d}, J=4.2 \mathrm{~Hz}, \mathrm{H}-3), 3.83(1 \mathrm{H}, \mathrm{dd}, J=8.1,4.2 \mathrm{~Hz}, \mathrm{H}-4)$, $4.62(1 \mathrm{H}, \mathrm{d}, J=8.1 \mathrm{~Hz}, \mathrm{H}-5), 4.69(1 \mathrm{H}, \mathrm{d}, J=8.1 \mathrm{~Hz}, \mathrm{H}-6), 2.17$ $\left(3 \mathrm{H}, \mathrm{s}, \mathrm{N}-\mathrm{CH}_{3}\right), 3.69\left(3 \mathrm{H}, \mathrm{s}, \mathrm{OCH}_{3}\right), 6.99-7.68(14 \mathrm{H}, \mathrm{Ar}-\mathrm{H})$.

Compound 3ab. Colourless oil; ${ }^{1} \mathrm{H}$ NMR (600 $\mathrm{MHz}, \mathrm{CDCl}_{3}$ ) $\delta_{\mathrm{H}} 5.52(1 \mathrm{H}, \mathrm{d}, J=4.2 \mathrm{~Hz}, \mathrm{H}-3), 4.07(1 \mathrm{H}, \mathrm{dd}, J=8.1,4.2 \mathrm{~Hz}, \mathrm{H}-$ 4), 4.75 (1H, m, H-5), 4.75 (1H, overlapped, H-6), 2.19 (3H, s, N$\left.\mathrm{CH}_{3}\right), 3.59\left(3 \mathrm{H}, \mathrm{s}, \mathrm{OCH}_{3}\right), 7.00-7.70(14 \mathrm{H}, \mathrm{Ar}-\mathrm{H})$.

\section{Neuroprotection bioassays}

Pheochromocytoma (PC12) cells were incubated in DMEM supplied with $5 \%$ fetal bovine serum and $5 \%$ equine serum as basic medium. PC12 cells in logarithmic phase were cultured at a density of 5000 cells per well in a 96-well microtiter plate. After $24 \mathrm{~h}$ incubation, the medium of the model group was changed to DMEM or basic medium with $15 \mu \mathrm{M} \mathrm{A} \beta_{25-35}$ for $48 \mathrm{~h}$ or basic medium with $50 \mathrm{nM}$ OKA for $24 \mathrm{~h}$. Test compounds dissolved in dimethyl sulfoxide (DMSO) were added to each well for $>1000$-fold dilution in the model medium at the same time. Each sample was tested in triplicate. After the incubation at $37{ }^{\circ} \mathrm{C}$ in $5 \% \mathrm{CO}_{2}$ for $24 \mathrm{~h}, 10 \mu \mathrm{L}$ of MTT (5 mg mL ${ }^{-1}$ ) was added to each well and incubated for another $4 \mathrm{~h}$; then liquid in the wells was removed. DMSO (100 $\mu \mathrm{L}$ ) was added to each well. The absorbance was recorded on a microplate reader (Bio-Rad model 550) at a wavelength of $570 \mathrm{~nm} .{ }^{37}$ Analysis of variance (ANOVA) followed by Newman-Keuls post hoc test were performed to assess the differences between the relevant control and each experimental group. $p$-Values of $<0.05,<0.01$, and $<0.001$ were regarded as statistically significant. Data were expressed as mean \pm SEM as indicated.

\section{Conflict of interest}

There are no conflicts of interest to declare. 


\section{Acknowledgements}

We are grateful to the Department of Instrumental Analysis, Institute of Materia Medica, Chinese Academy of Medical Sciences and Peking Union Medical College, for the measurement of the UV, IR, CD, NMR, and HRESIMS spectra. This research program is financially supported by the National Natural Science Foundation of China (No. 21272278) and the National Megaproject for Innovative Drugs (No. 2012ZX09301002-002).

\section{Notes and references}

1 R. L. Pan and Z. Y. Zhu, World Notes Plant Medicine, 1990, 5(6), 243-247.

2 C. Yenjai, S. Sripontan, P. Sriprajun, P. Kittakoop, A. Jintasirikul, M. Tanticharoen and Y. Thebtaranonth, Planta Med., 2000, 66, 277-279.

3 D. Y. Shen, Y. Y. Chan, T. L. Hwang, S. H. Juang, S. C. Huang, P. C. Kuo, T. D. Thang, E. J. Lee, A. G. Damu and T. S. Wu, J. Nat. Prod., 2014, 77, 1215-1223.

$4 \mathrm{~W}$. Maneerat, W. Phakhodee, S. Cheenpracha, T. Ritthiwigrom, S. Deachathai and S. Laphookhieo, Phytochemistry, 2013, 88, 74-78.

5 H. M. Xia, C. J. Li, J. Z. Yang, J. Ma, X. G. Chen, D. Zhang, L. Li and D. M. Zhang, J. Nat. Prod., 2014, 77, 784-791.

6 B. Kongkathip, N. Kongkathip, A. Sunthitikawinsakul, C. Napaswat and C. Yoosook, Phytother. Res., 2005, 19, 728-731.

7 W. Maneerat, W. Phakhodee, T. Ritthiwigrom, S. Cheenpracha, T. Promgool, K. Yossathera, S. Deachthai and S. Laphookhieo, Fitoterapia, 2012, 83, 1110-1114.

8 H. M. Xia, C. J. Li, J. Z. Yang, J. Ma, Y. Li, L. Li and D. M. Zhang, Phytochemistry, 2016, 130, 238-243.

9 W. W. Song, G. Z. Zeng, W. W. Peng, K. X. Chen and N. H. Tan, Helv. Chim. Acta, 2014, 97, 298-305.

10 H. Liu, C. J. Li, J. Z. Yang, N. Ning, Y. K. Si, L. Li, N. H. Chen, Q. Zhao and D. M. Zhang, J. Nat. Prod., 2012, 75, 677-682.

11 A. C. Adebajo, E. O. Iwalewa, E. M. Obuotor, G. F. Ibikunle, N. O. Omisore, C. O. Adewunmi, O. O. Obaparusi, M. Klaes, G. E. Adetogun, T. J. Schmidt and E. J. Verspohl, J. Ethnopharmacol., 2009, 122, 10-19.

12 W. Maneerat, T. Ritthiwigrom, S. Cheenpracha and S. Laphookhieo, Phytochem. Lett., 2012, 5, 26-28.

13 G. T. Liu, W. X. Li, Y. Y. Chen and H. L. Wei, Drug Dev. Res., 1996, 39, 174-178.

14 K. N. Prasad, H. H. Xie, J. Hao, B. Yang, S. X. Qiu, X. Y. Wei, F. Chen and Y. M. Yue, Food Chem., 2010, 118, 62-66.

15 H. Liu, F. Li, C. J. Li, J. Z. Yang, L. Li, N. H. Chen and D. M. Zhang, Phytochemistry, 2014, 107, 141-147.

16 J. Liu, C. J. Li, L. Ni, J. Z. Yang, L. Li, C. X. Zang, X. Q. Bao, D. Zhang and D. M. Zhang, RSC Adv., 2015, 5, 80553-80560.

17 Y. Q. Du, H. Liu, C. J. Li, J. Ma, D. Zhang, L. Li, H. Sun, X. Q. Bao and D. M. Zhang, Fitoterapia, 2015, 103, 122-128. 18 Q. Zhao, J. Z. Yang, C. J. Li, N. H. Chen and D. M. Zhang, J. Asian Nat. Prod. Res., 2011, 13, 361-366.
19 H. Achenbach, C. Renner and R. Waibel, Liebigs Ann., 1995, 1327-1337.

20 K. Freter and V. J. Fuchs, J. Heterocycl. Chem., 1982, 19, 377379.

21 M. J. Frisch, G. W. Trucks, H. B. Schlegel, G. E. Scuseria, M. A. Robb, J. R. Cheeseman, G. Scalmani, V. Barone, B. Mennucci, G. A. Petersson, H. Nakatsuji, M. Caricato, X. Li, H. P. Hratchian, A. F. Izmaylov, J. Bloino, G. Zheng, J. L. Sonnenberg, M. Hada, M. Ehara, K. Toyota, R. Fukuda, J. Hasegawa, M. Ishida, T. Nakajima, Y. Honda, O. Kitao, H. Nakai, T. Vreven, J. A. Montgomery, J. E. Peralta, F. Ogliaro, M. Bearpark, J. J. Heyd, E. Brothers, K. N. Kudin, V. N. Staroverov, R. Kobayashi, J. Normand, K. Raghavachari, A. Rendell, J. C. Burant, S. S. Iyengar, J. Tomasi, M. Cossi, N. Rega, N. J. Millam, M. Klene, J. E. Knox, J. B. Cross, V. Bakken, C. Adamo, J. Jaramillo, R. Gomperts, R. E. Stratmann, O. Yazyev, A. J. Austin, R. Cammi, C. Pomelli, J. W. Ochterski, R. L. Martin, K. Morokuma, V. G. Zakrzewski, G. A. Voth, P. Salvador, J. J. Dannenberg, S. Dapprich, A. D. Daniels, Ö. Farkas, J. B. Foresman, J. V. Ortiz, J. Cioslowski and D. J. Fox, Gaussian 09, Revision B. 01, Gaussian, Inc., Wallingford, CT, 2009.

22 N. Berova, L. Bari and G. Pescitelli, Chem. Soc. Rev., 2007, 36, 914-931.

23 J. Frelek, M. Geiger and W. Voelter, Curr. Org. Chem., 1999, 3, 117-146.

24 L. D. Bari, G. Pescitelli, C. Pratelli, D. Pini and P. J. Salvadori, J. Org. Chem., 2001, 66, 4819-4825.

25 N. C. Ma, K. M. Wu and L. Huang, Eur. J. Med. Chem., 2008, 43, 1781-1784.

26 N. C. Ma, K. M. Wu and L. Huang, J. Heterocycl. Chem., 2008, 45, 785-787.

27 J. M. Seco, E. Quinoa and R. Riguera, Chem. Rev., 2004, 104, 17-117.

28 G. Q. Li, Z. W. Deng, J. Li, H. Z. Fu and W. H. Lin, J. Chin. Pharm. Sci., 2004, 13(2), 81-86.

29 M. F. Grundon and S. A. Surgenor, J. Chem. Soc., Chem. Commun., 1978, 14, 624-626.

30 J. J. Chen, C. Y. Duh and H. Y. Huang, Planta Med., 2003, 69(6), 542-546.

31 A. Ahond, C. Poupat and J. Pusset, Phytochemistry, 1979, 18, 1415-1416.

32 Y. D. Min, H. C. Kwon, M. C. Yang, K. H. Lee, S. U. Choi and K. R. Lee, Arch. Pharmacal Res., 2007, 30(1), 58-63.

33 J. Pusset, J. L. Lopez, M. Pais, M. A. Neirabeyeh and J. M. Veillon, Planta Med., 1991, 57, 153-155.

34 M. X. You, S. Purevsuren and C. Q. Hu, Nat. Prod. Res. Dev., 2008, 20, 647-649.

35 F. Zhang, Y. N. Yang, X. Y. Song, S. Y. Shao, Z. M. Feng, J. S. Jiang, L. Li, N. H. Chen and P. C. Zhang, J. Nat. Prod., 2015, 78, 2390-2397.

36 S. F. Chu and J. T. Zhang, Acta Pharm. Sin. B, 2014, 4(6), 417423.

37 M. Pieroni, S. Girmay, D. Q. Sun, R. Sahu, B. L. Tekwani and G. T. Tan, ChemMedChem, 2012, 7(11), 1895-1900. 